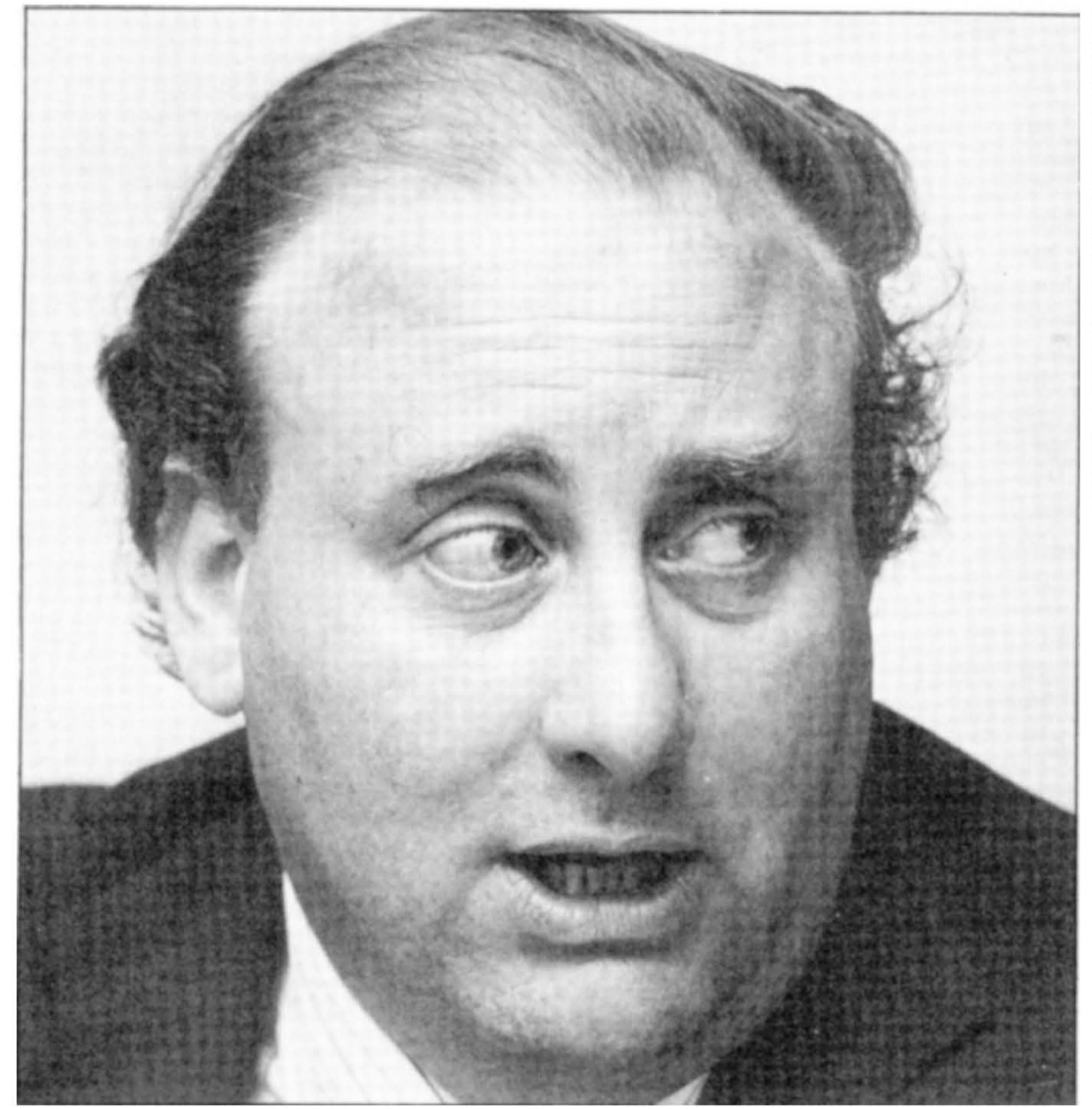

\section{Marshall the energy}

\section{A profile of Eric Varley's Chief Scientist by David Fishlock}

THE late Sir John Cockcroft, founderdirector of the Atomic Energy Research Establishment, Harwell, in the early 1950 s, was offered the post of Chief Scientific Adviser to the Cabinet. He accepted but retained his job as director of one of Britain's biggest research centres. Few today even recall that Cockcroft ever held the post in Whitehall, so slight was his influence in the broader affairs of government. Dr Walter Marshall, present Director of Harwell, was expressly warned of this unhappy pecedent when, last summer, Mr Eric Varley, Secretary of State for Energy, offered him the post of Chief Scientist to his science-starved department. Marshall, however, would nonetheless accept only on condition that he retained his job as Director of Harwell, Britain's-if not Europe'smost powerful energy research and development centre.

For Marshall, still a theoretical physicist at heart, whose own research earned him election into the Royal Society while still in his thirties, the most worthwhile job in the world is to be chief executive of this big science machine. Knowing that this is so is one important reason why morale is so high among the 5,000 staff of the Research Group of the UK Atomic Energy Authority (UKAEA), for which Marshall is the Board member responsible. But the Whitehall post, in which he would take a seat alongside the four existing deputy secretaries under Sir Jack Rampton in the Department of Energy, could expand vastly his influence over energy research and development in Britain. Coordination in this area, at a time when the emphasis was shifting from competition to conservation, would plainly be an important part of the role of government, as it became increasingly deeply embroiled in the activities of private as well as state-owned energy industries.

Even so, the twin jobs of advising both the Energy Secretary and his own boss Sir John Hill, Chairman of the AEA, could begin to work only if there existed a special relationship between Hill, as the Energy Secretary's adviser on the largest single sector of energy research and development, and Marshall, as his personal research adviser. But Marshall holds Hill in high esteem, not least for the support given Harwell during the difficult years when the laboratory was attempting to re- build its reputation with a new and far more commercial approach, in face 总 of great scepticism from the $\because$ scientific community as well as from private industry. They devised the kind . of formula that can work only between two people in closest rapport, to avoid mutual interference within each other's parish in advising the Secretary of State for Energy.

Walter Charles Marshall, 43, joined Harwell from Birmingham University in 1954. Just six years later he became Head of Theoretical Physics, and in 1966 Deputy Director, Two years later to has appointed Director of Harwell under Dr J. B. Adams, then Board member for research of the UKAEA. When Adams resigned the following year to take charge of CERN's plans for the $300 \mathrm{GeV}$ accelerator, Marshall was appointed Director of the Research Group of the UKAEA. In 1972 he became its Board member for research, with full control of its research budget of $£ 25$ million.

By this time the prodigious energies of the burly young Welshman were already a legend--and not only at Harwell. In 1969 Dr Alvin Weinberg, then Director of Oak Ridge National Laboratory, reflecting upon a period Marshall had spent with him in his early thirties, remarked to me that had he remained much longer he would have taken over Oak Ridge.

But Harwell, by the mid-1960s, was presenting a challenge of a different kind. It was a research centre searching for a new mission. The basic physics and chemistry required to make nuclear weapons and lay the foundations for a nuclear power programme had been taken up by other laboratories, more firmly orientated towards engineering requirements. Harwell, some said, was becoming increasingly irrelevant. (Nature itself, in an editorial in October, 1967, argued that it should be closed down.)

One course of action open to the UKAEA was to cut the Research Group-then some 6,000 strong-back to a size commensurate with the mission remaining, mostly work for the fast reactor. This implied a reduction to about one-third of its size. The Government itself was well aware at the time of one drawback to this course of action, that those industries most urgently in need of new technical talent, such as the mechanical engineering industries, were the least likely to be enthusiastic about hiring redundant Harwell staff. Marshall and his colleagues, however, raised another important reservation-that a Harwell shrunk to one-third of its size simply would not be up to the very demanding business of nuclear energy research and development. So many questions remained unanswered about the fast 
reactor that nobody could possibly predict, when trouble struck, which of its vast array of techniques and talent would be needed.

Marshall and his colleagues were vehemently opposed to either closure or a major reduction in strength. As he put it in a paper published by the National Academy of Sciences last year: "When a group of talented scientists and engineers have been brought together into a national laboratory and they have partially fulfilled their original mission, it seems to me unimaginative and wrong simply to disperse the ability ... national laboratories are a national asset, but they should be encouraged to charze their orientation from time to time'.

In other words, Harwell was seeking a new national mission to augment a diminishing role in nuclear fission. The most obvious subject was nuclear fusion, but this had already been hived off to a new centre, the Culham Laboratory; while Marshall himself, once deeply into the physics of fusion, had turned to solid state physics because of frustration with the chaotic state of plasma physics in the mid1960s.

The mission conceived by Adams, Marshall and their colleagues was born of an awareness that "British scientists regularly produced good scientific ideas which led fairly rapidly to an improvement in the balance of payments of other countries but not of our own" (The New Scientists, OUP, 1971). At Harwell they had the skills, the equipment, and the proven ability to organise these facilities into effective problem-solving teams. The mission they sought was the freedom to offer these facilities to industrial companies, on an exclusive basis, in an endeavour to help them to innovate.

The Labour Government, well aware that Harwell was only the first of a number of national laboratories whose original missions were drawing to a close, looked kindly on Harwell's idea. It even endorsed the proposal that Harwell should flout all traditions of British government-funded science and instead of making its research freely available to all-comers (as taxpayers) should work exclusively with chosen industrial partners. With characteristic irreverence the idea was dubbed "the principle of maximum unfairness".

The difficulty, as Marshall records in The New Scientists was the "large number of arguments against the general idea, mostly drawn to our attention very forcibly by other people." Harwell's own attitude at the time was somewhat ambivalent, with many of the physicists and chemists opposed to the scheme, though the metallurgists, engineers, corrosion experts and so on were strongly in favour.
Other opponents included industry itself, whose response was entirely unambiguous. "Industry simply did not want us, and most people sought strongly to discourage us."

Marshall must take a major share of the credit for the success of the 'Harwell experiment' in which the portion of its income outside the Atomic Energy Vote has grown steadily to some $£ 8$ million last year, about $40 \%$ of the laboratory's budget.

Marshall's industry-orientated research effort has, however, had its full share of disappointments and failures. A prototype isotope-powered heart pacemaker failed in a patient. A promising new method of desalinating sea water was turned down by the government as uneconomic when funds were sought for a demonstration plant. Perhaps most disappointing of all was the decline and fall of carbon fibre.

Last summer he shouldered the task of bringing the deductive logic of science to bear on the affairs of the new energy department. In terms of influence the post had some obvious attractions, for the department is nominally responsible for an outlay on energy research and development which this year will total $£ 120$ million. The post also provided a seat at the table of departmental scientific advisers counselling the Cabinet on scientific affairs.

The obverse of the coin is that the research resources of the energy department are unquestionably undernourished. Most of the $£ 120$ million is administered by the various energy industries and agencies, as the accompanying table shows. As Marshall told the Select Committee on Science and Technology recently, his freedom for action in terms of research funds is restricted at present to a mere $£ 200,000$ - the cash allocated last spring to set up the Energy Technology Support Unit at Harwell, which is appraising alternative energy options open to Britain.

But as Chairman of ACORD, the Advisory Committee on Research and Development for the energy industries -traditionally an independent appointment but one Marshall insisted on taking himself-he can encourage a spirit of cooperation where once there was fierce competition, and of concern to conserve rather than to promote further use of particular fuels. For the moment the emphasis is on technical services and what the application of research data already existing - perhaps garnered a decade ago-can do quickly to reduce energy consumption in industry.

Outside ACORD, to which each of the state-owned energy industries will be submitting its annual report on research for appraisal this spring, the
Department of Energy is spending about $£ 21$ million in the current year on research contracts placed with Government and industrial laboratories. Half of this sum is committed, however, to the Anglo-German-Dutch gas centrifuge project for uranium enrichment. The only laboratory that came under the direct control of the department's Chief Scientist, namely the Safety in Mines Research Establishment, was transferred to the new Health and Safety Commission earlier this year.

Several problems therefore loom large this spring for Dr Marshall. First, he has a major part to play in preparing a paper for the Cabinet putting forward the case for a new phase in the development of the fast breeder reactor, far and away the most rewarding prospect in sight for research and development in energy conservation. The new phase, however, will involve a sum of the magnitude of Britain's contribution to Concorde, for it must include a large scale demonstration power station using the sodium-cooled fast reactor.

Second, he has to coordinate Britain's role in the energy research programme of the International Energy Agency which-largely, it is said, because of his own influence--blossomed abruptly in January with a series of proposals for multi-national ventures, with Britain taking the lead in coal technology.

A third and possibly less tractable problem for Marshall is to create a research arm under his own control to the department's Offshore Supplies Office in Glasgow. Only when thus equipped will the department feel competent to monitor what must surely be a rapidly burgeoning budget for offshore and seabed research and development contracts placed with other British laboratories.

Fourth, he must strengthen his own scientific secretariat in the department, numbering merely 30 at present, and strongly orientated towards coal-a legacy of its origins in the erstwhile Ministry of Fuel and Power.

A scientist on the Cabinet Office committee of departmental chief scientific advisers has remarked that Walter Marshall tends to raise eyebrows among his older and-in terms of Whitehall politics-much more experienced colleagues by starting his contributions: "I don't know what you fellows think but at Harwell..." Marshall is proud of the way he has rekindled the vitality of this research centre, transforming it into a brisk, businesslike organisation, second-tonone in the management of research projects. Nobody would be very surprised if Walter Marshall now turned his top Harwell management loose on the problem of reshaping the nation's energy research and development effort. 